\title{
American Pediatric Society Presidential Address 1995: Disease, War, and Biology: Languages for Medicine-and Pediatrics
}

\author{
CHARLES R. SCRIVER \\ DeBelle Laboratory for Biochemical Genetics, McGill University-Montreal Children's Hospital Research \\ Institute, Montreal, Quebec H3H IP3, Canada
}

\section{PREFACE}

Almost 20 years ago, at the Annual meeting of the Society for Pediatric Research in St. Louis, the President spoke on "Genetics: A Voyage of Discovery" (1). Now there is another opportunity for the same person to address the annual meeting of the Academic Pediatric Societies. Although the role of the APS President is mainly honorific, the occasion can be used to transmit a point of view; my theme reflects my own continuing "voyage of discovery."

The fourth Canadian to be President of the American Pediatric Society is myself, an honor given to me by the membership. I deeply appreciate it. Between Scriver and the first Canadian president, William Osler, in 1892, 103 years have elapsed. (The other Canadian presidents were: Alexander Blackader and Alan Ross. The latter gave me my first and only job; this Address is dedicated to him.) The early Presidents of APS themselves assembled the scientific programs for the annual meetings and, in 1892, Osler selected 23 abstracts submitted by a membership of 50 (2). In 1995, 16 Officers of the three pediatric academic societies (APS, SPR, and APA), a technically fluent staff of six and two dedicated computers assembled the program from 2380 abstracts read and ranked by a battalion of reviewers and submitted by a collective membership of several thousand. Would Osler recognize this gargantuan creature?

The thread that binds us together in San Diego in 1995 is "pediatrics" (Table 1); it is the only word common to the names of the three organizations sponsoring this meeting. Yet most of us have special interests and affiliations which if strong enough will sever our attachments to the parent organizations and discipline. The President's address in 1995 is an inquiry into the choice between federalism or separatism in medicine in general, and in pediatrics in particular; an issue recognized long ago by Osler (and one rather familiar to Canadians in the political context of the relationship between Quebec and Canada).

Table 1. The word common to the pediatric academic societies AMERICAN PEDIATRIC SOCIETY SOCIETY FOR PEDIATRIC RESEARCH AMBULATORY PEDIATRIC ASSOCIATION
I

Osler's Language of Disease

Knowledge of history, even recent history, cannot be taken for granted in our present era-when there is so little regard for history itself. History is about "questions put to the past that resonate in the present (3). A historian writing about the twentieth century observes that "the destruction of the past, or rather the social mechanisms that link one's contemporary experience to that of earlier generations, is one of the most characteristic and eerie phenomena of the late twentieth century" (4). Even within the little microcosm of pediatrics, our contemporary problems in APS are linked to those of earlier generations (5), yet we ignore that fact at our immediate peril. Although today is the last day of the past, it is also the first day of the future.

The Annual Meeting is a tribal ritual that brings together, in our case, three different academic societies each dedicated to pediatrics and science. Pediatric science and clinical pediatrics are not the same (Table 2). Science is an attack on ignorance, and what is not known is more interesting than what is known; science is a public activity; it is driven by hypotheses. Medicine uses what is known in a private relationship with the patient, and physicians must make decisions with the information at hand, incomplete as it may be.

Members of medical research societies tend to be physicianscientists and as such are persons inhabited by two contending agendas. At this level there is an intrapersonal splintering of identity. When the scientist and the physician are different persons, there is a further division of identity at the interpersonal level. This problem can be solved by the demise of the physician-scientist - an unhappy solution, in my opinion. Alternatives include making non-M.D. and M.D. scientists and their physician counterparts all equal partners in the medicine of the molecular era. It can happen if we train ourselves well

Table 2. Medicine and science: physicians and scientists: different entities

\begin{tabular}{cl}
\hline Science/Scientist & \multicolumn{1}{c}{ Medicine/Physician } \\
\hline - Concerned with what & $\bullet$ Uses what is known \\
is not known & - A "private" relationship \\
- A "public" activity & - Decisions depend on facts \\
- Driven by hypotheses &
\end{tabular}




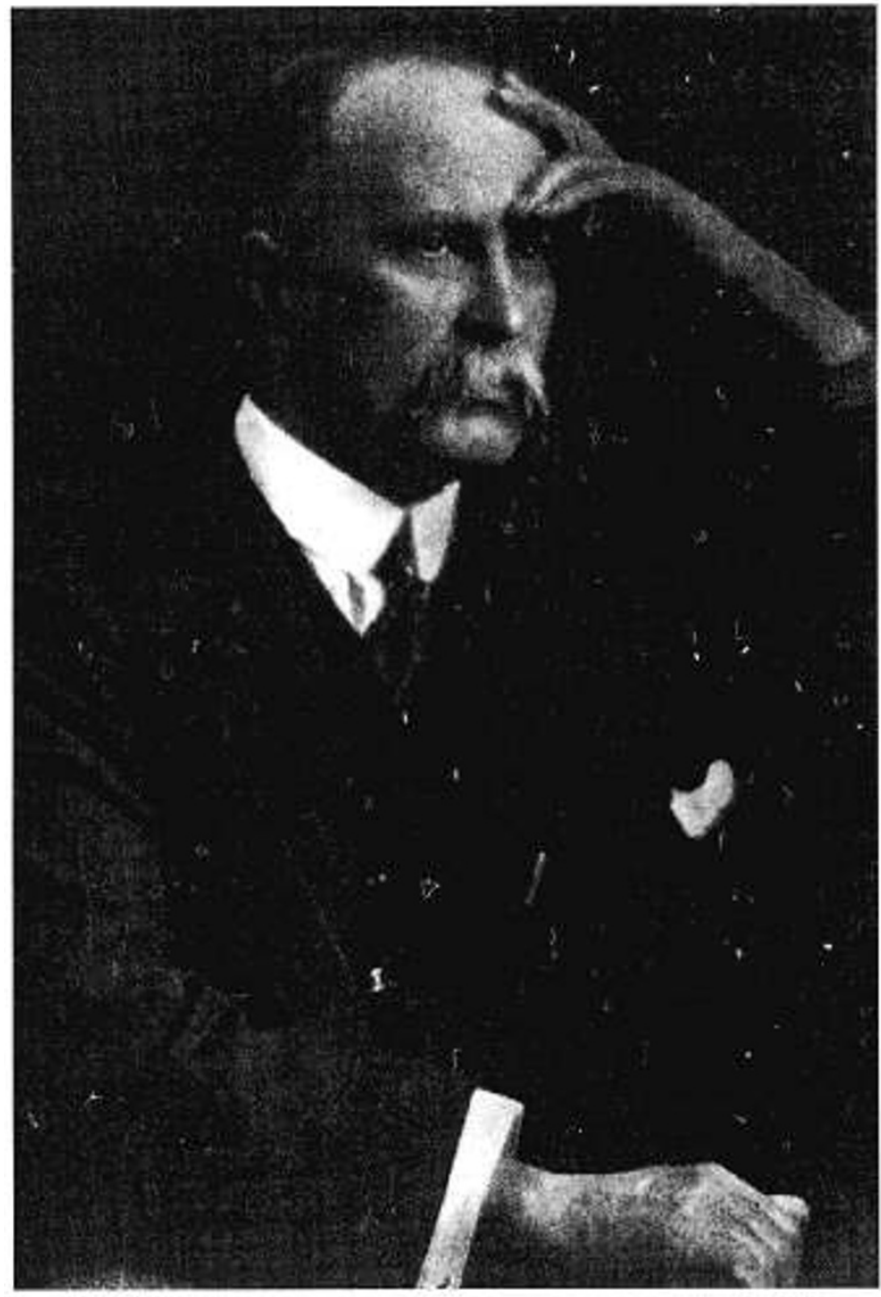

Figure 1. William Osler, M.D.C.M., a major figure in medicine first in Canada, then in the United States and last in England; President of the American Pediatric Society in 1892.

Table 3. Osler's language of disease and its modern contexts MANIFESTATIONS $\leftarrow$ PATHOGENESIS $\leftarrow$ CAUSE Diagnosis

Treatment

\begin{tabular}{|c|c|c|}
\hline "Specialism" & $\begin{array}{l}\text { - } \quad \text { Cell biology } \\
\text { - } \quad \text { Pathology, } \\
\text { histology, } \\
\text { physiology, etc.] }\end{array}$ & $\begin{array}{ll}\text { - } & \text { Biology } \\
\text { - } & \text { Genetic } \\
& \text { epidemiology }\end{array}$ \\
\hline
\end{tabular}

Table 4. The splintering of medicine

\begin{tabular}{clll}
\hline Profession & \multicolumn{1}{c}{ Specialty } & \multicolumn{1}{c}{ Subspecialty } & Sub-Sub. . \\
\hline Medicine & Internal Medicine & Cardiology & "etcetera, \\
& Surgery & Gastroenterology & etcetera, \\
& Pediatrics & Infectious dis. & etcetera" \\
& Obstetrics & Nephrology & \\
& Etc. & Neurology & \\
& & Nutrition & \\
& & Etc. \\
- Medical & $\bullet$ & Etc. \\
model(s) & $\bullet 1^{\circ}$ Care & $\bullet$ CONTEXTS \\
of disease & $\bullet$ Rensultations & technostic \\
& $\bullet$ Research & $\bullet$ Treatments \\
& $\bullet$ Training & $\bullet$ Training \\
\hline
\end{tabular}

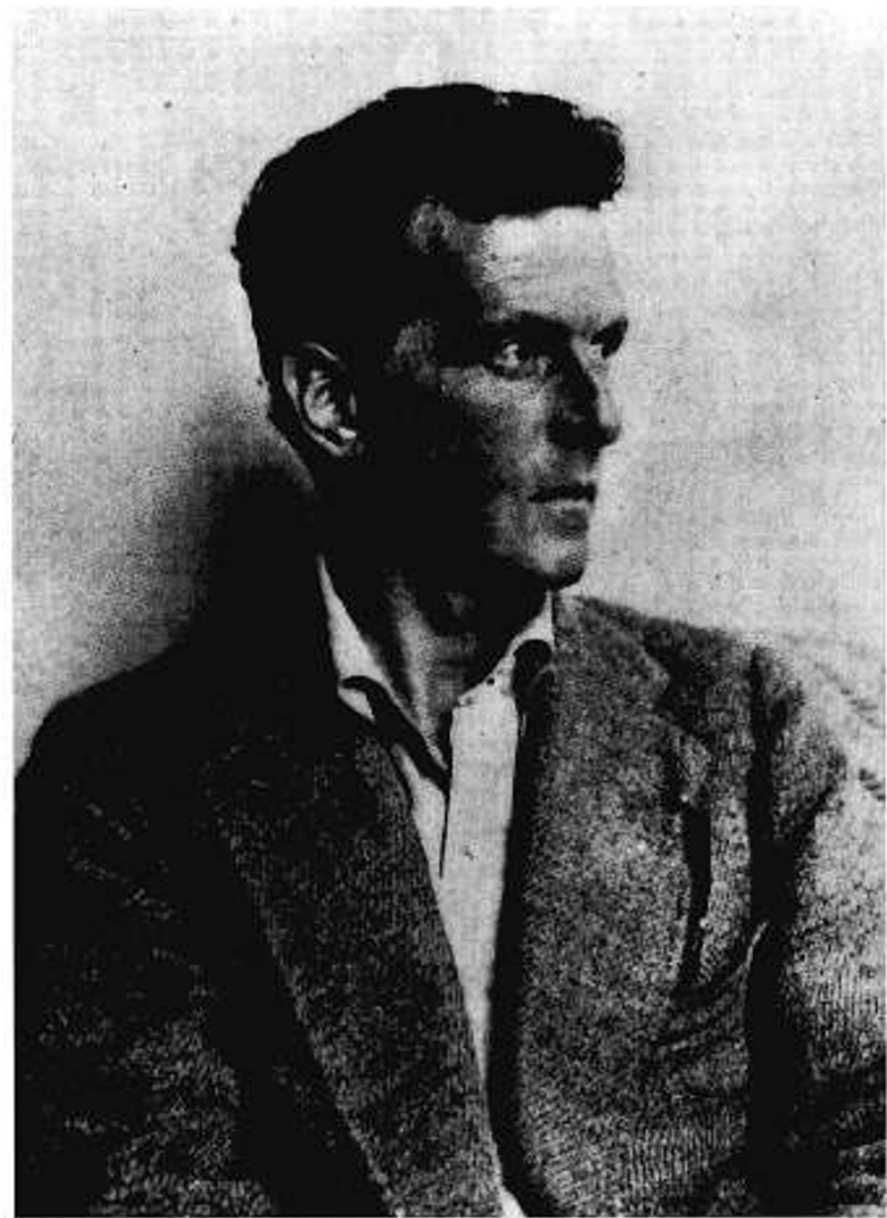

Figure 2. Ludwig Wittgenstein, philosopher, student of engineering, architecture, and medicine, one-time elementary school teacher and hospital porter, and finally Cambridge don.

$(6,7)$, and it will happen when we share a common language; I will suggest what that language must be.

The Archives of the American Pediatric Society record that it was "founded in 1888 to bring together men and women for the advancement of the study of children and their diseases, for the prevention of illness and the promotion of health in childhood, for the promotion of pediatric education and research,

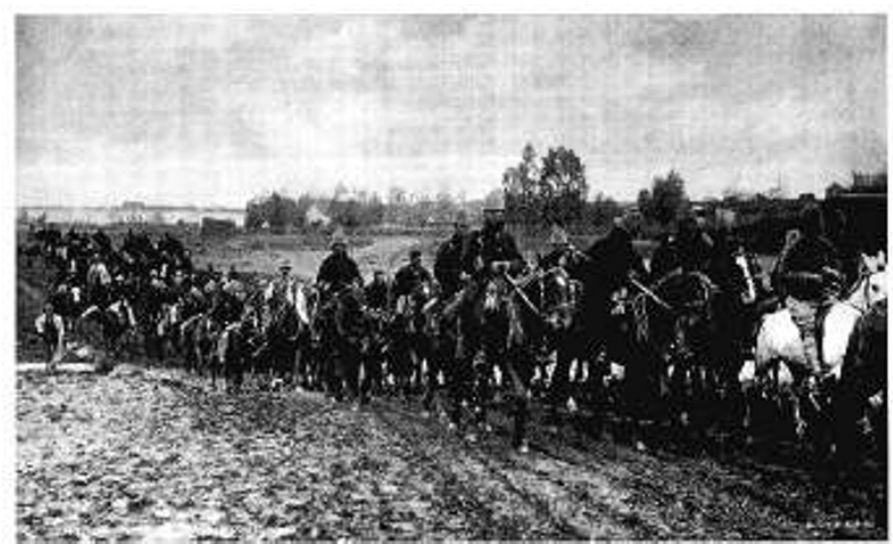

Figure 3. The Leicester Mounted Infantry retreating from Ladysmith, Boer War, South Africa, Oct. 26, 1899. (Reproduced with permission from the Royal Photographic Society, Bath, UK.) 


\section{Pediatrics in a Changing World}

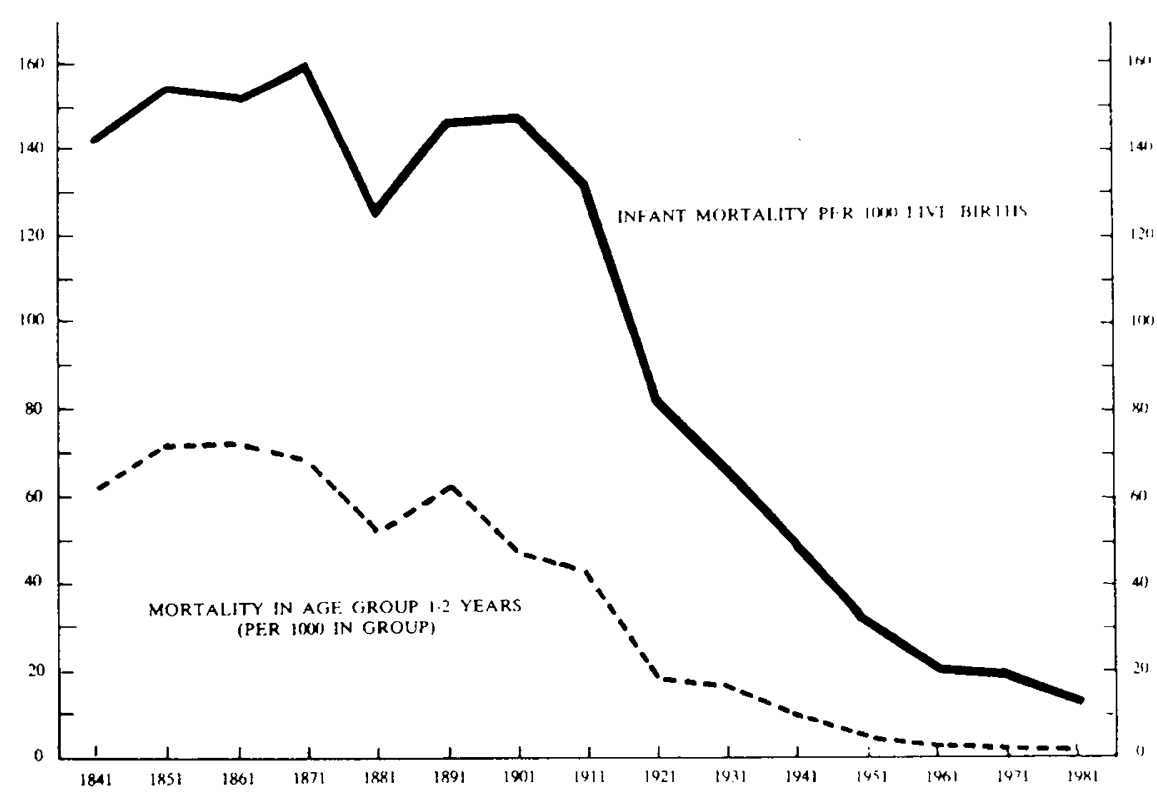

Figure 4. The effect on mortality rates of a Parliamentary Act to improve maternal and child health in the United Kingdom following the Boer War. [Taken from Forfar (11).]

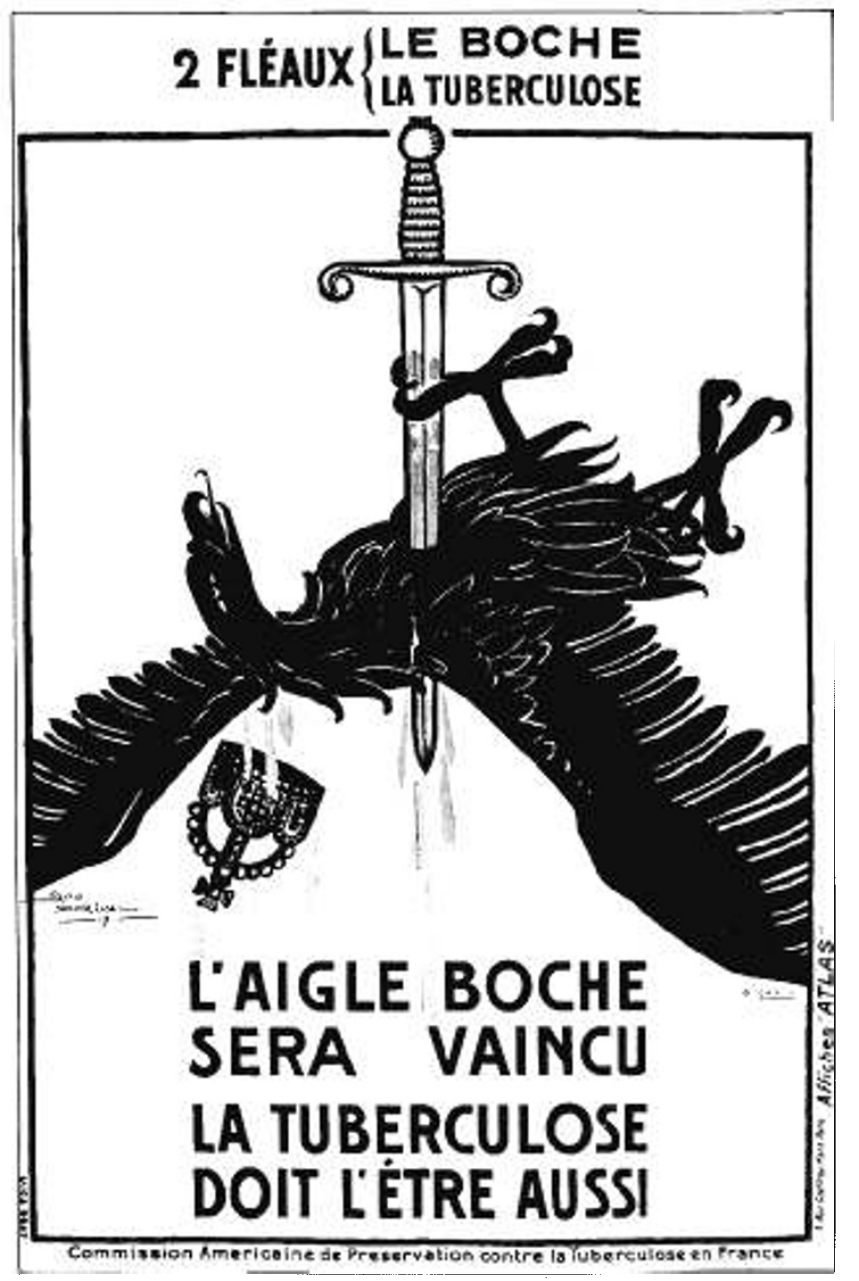

Figure 5. Medicine adopts the language of war. (Reproduced from Joseph Darracott: The First World War in Posters. Dover Publications, New York, 1974, p. 54.) and to honor those who by their contributions to pediatrics have aided in its advancement" (5). The fourth Presidential Address, entitled "Remarks on Specialism," was delivered by William Osler on May 2, 1892, in Boston to 21 assembled members of the Society (2). Osler (Fig. 1), the great generalist in medicine, opined that there were "no more dangerous members of our [medical] profession... than those born into it ... as specialists" (8). The President was not being reactionary, although the self-identified "pediatrists" of 1892 might have thought so. On the other hand, Osler was striving to take medicine beyond trade and give it an intellectual foundation and a universal language. His approach to medicine (Table 3) sought to interpret the manifestations of disease in a vocabulary of signs and symptoms, so that diagnosis and treatment had a logic. Here, he accepted the relevance of specialism (or the form of the language in my analogy); diagnoses in pediatrics would of course have particular contexts. Osler knew that the clinical manifestations of a disease were reflections of its pathogenesis; and, histology, physiology, and pathology (or cell biology in today's terminology), provided the grammar behind the vocabulary. Cause of disease is the deep grammar in my analogy. In Osler's era, disease would have been seen largely as the result of external agents doing harm; but better understood now in terms of biological paradigms (see below) and their partner-genetic epidemiology.

Osler consolidated his language for medicine in his textbook The Principles and Practice of Medicine, first published in 1892 and still in print in 1947, along with its many emulators. The concepts that informed his book filtered into his Presidential address to the newly declared, self-identified specialists in children's diseases. They also penetrated Flexner's famous report in 1910 on medical education and training in the United States and Canada. 
The future that Osler addressed on that day in May 1892 has unfolded as he feared it would. There is a fierce taxonomy within medicine (Table 4). Specialism is the rule, specialty Boards administer it, and subspecialism drives the fracture lines deeper into medicine's tectonic plate-especially into the continent of internal medicine (9) inhabited by our neighbors at the 1995 meeting. Osler's unifying language will not prevail universally when we stream out later this morning into smaller rooms identified by the flags of subspecialism taxonomy under which we will speak in our own tongues.

The problems of language and taxonomy are not new. Wittgenstein (Fig. 2) said language "cannot contain an analysis of the conditions of its own application"; and for taxonomy he developed a method in which members of a group or class would share common characterization without any of these being essential for membership of the group or class (10). To illustrate the precept, Wittgenstein offered an example: "The strength of a thread does not reside in the fact that the same fibre runs through its whole length, but in the overlapping of many fibres" (Wittgenstein, Philosophical Investigations, para 67). The philosopher's language and metaphor are transparent if the example is collagen and cell biology is the translator. Osler's language, at one time so transparent, has been replaced by many private dialects in pediatrics and elsewhere in medicine. And during the past century, there has been an intruder using the language of war.

\section{II}

\section{A Language of War for Medicine}

Long before the Vietnam War, there was the Boer War (Fig. 3). Britain sent 450000 men to South Africa in 1899-1902; 29000 were killed or died of their wounds; another 16000 died by disease; and Britain was losing the war. As it progressed, enlistment of civilians faltered largely because their poor physical condition made the recruits ineligible. The shock of discovery about the state of health at home provoked a response and Britain passed an Act for Maternal and Child health (11). Thereafter, the nation's health began to improve, and rates of newborn and infant mortality declined dramatically and consistently (Fig. 4). It was an unexpected benefit of the war.

The Boer War was followed by The World War (now called the First World War; what a century we inhabit!). In that conflict 4 million European soldiers lost their lives on the Western Front alone. To put it in relative terms, had this been the year 1914 and this audience had all enlisted or been conscripted over the next 4 years, one quarter of us would not

Table 5. The language of war in medicine: disease as the enemy and medicine as a war

- Killer disease

- Breakthrough discovery/treatment

- Crush

- Eradicate

- (Cobalt) bomb

- War on cancer/polio/. . .

- Entrenched
DEATHS OF CHILDREN AGED UNDER 5 YEARS

AS A PERCENTAGE OF DEATHS AT ALL AGES

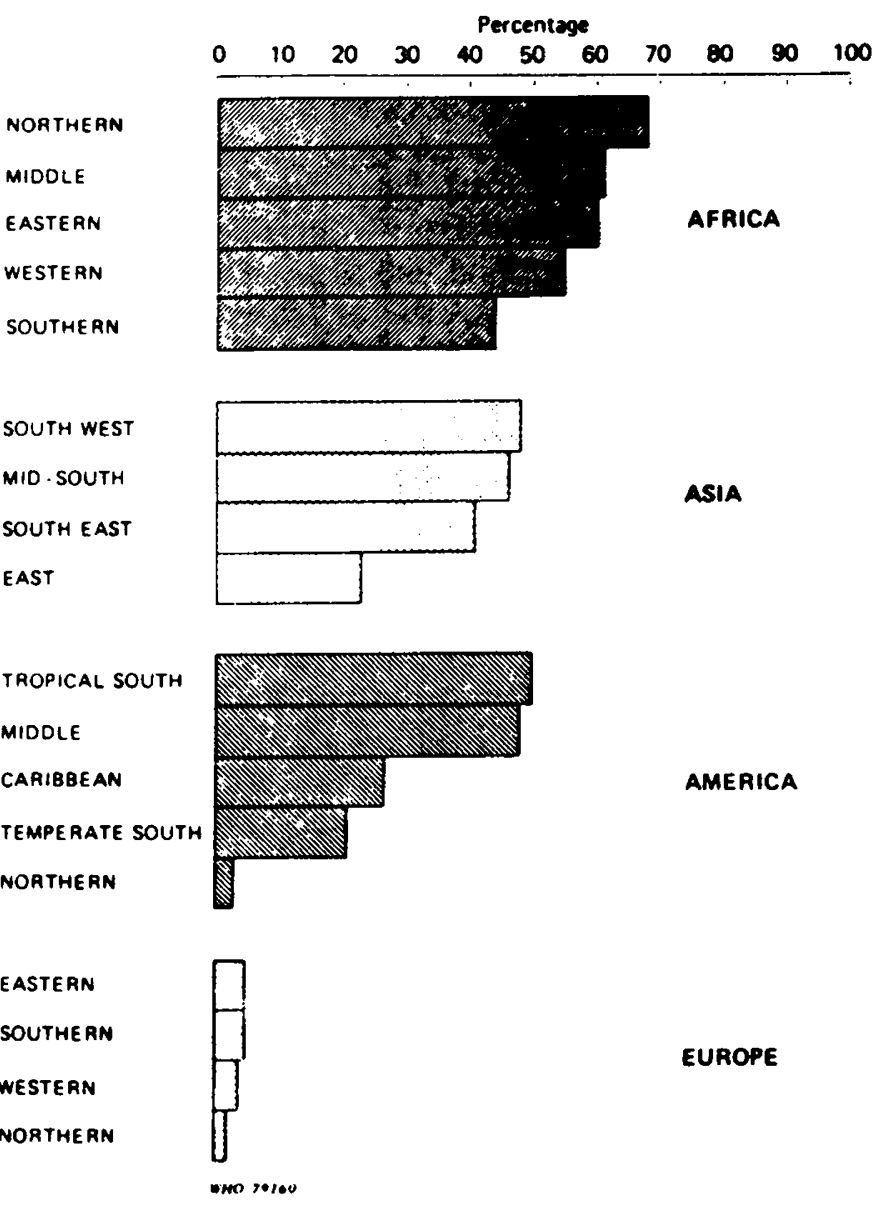

Figure 6. The impact of improved child health, or its absence, on under-5year mortality rates in regions of the world. (From World Health Organization Statistics, 1980.)

return to our jobs. Imagine the effect of that on academic pediatrics! Combat itself did not account for all of the lives lost. Disease was the other enemy. Two scourges (fléaux) are depicted in a famous French poster published in 1917 (Fig. 5); one is the Germany enemy, the other is tuberculosis. Both had to be vanquished, and infiltration of the language of war into the language of medicine was underway (Table 5). Disease became an enemy and the words and phrases of war, such as killer, breakthrough, crush, eradicate, bomb, and entrenched became current. The words are metaphors and metaphors are a conceptual system (12). How we have been thinking about human disease for most of the twentieth century is revealed in the vernacular language of medicine-as-war.

War has campaigns and battles. Campaigns for better sanitation, nutrition, and immunization improved collective health, notably of infants and children. Wherever these campaigns were successful, childhood mortality rates fell below those in other parts of the world (Fig. 6). Better child health improves life expectancy and life expectancy at birth has increased in most parts of the world during the past half century (Fig. 7). An obligatory effect of increased life expectancy is an increased rate of population growth, a problem we now recognize as one 


\section{Life expectancy at birth}

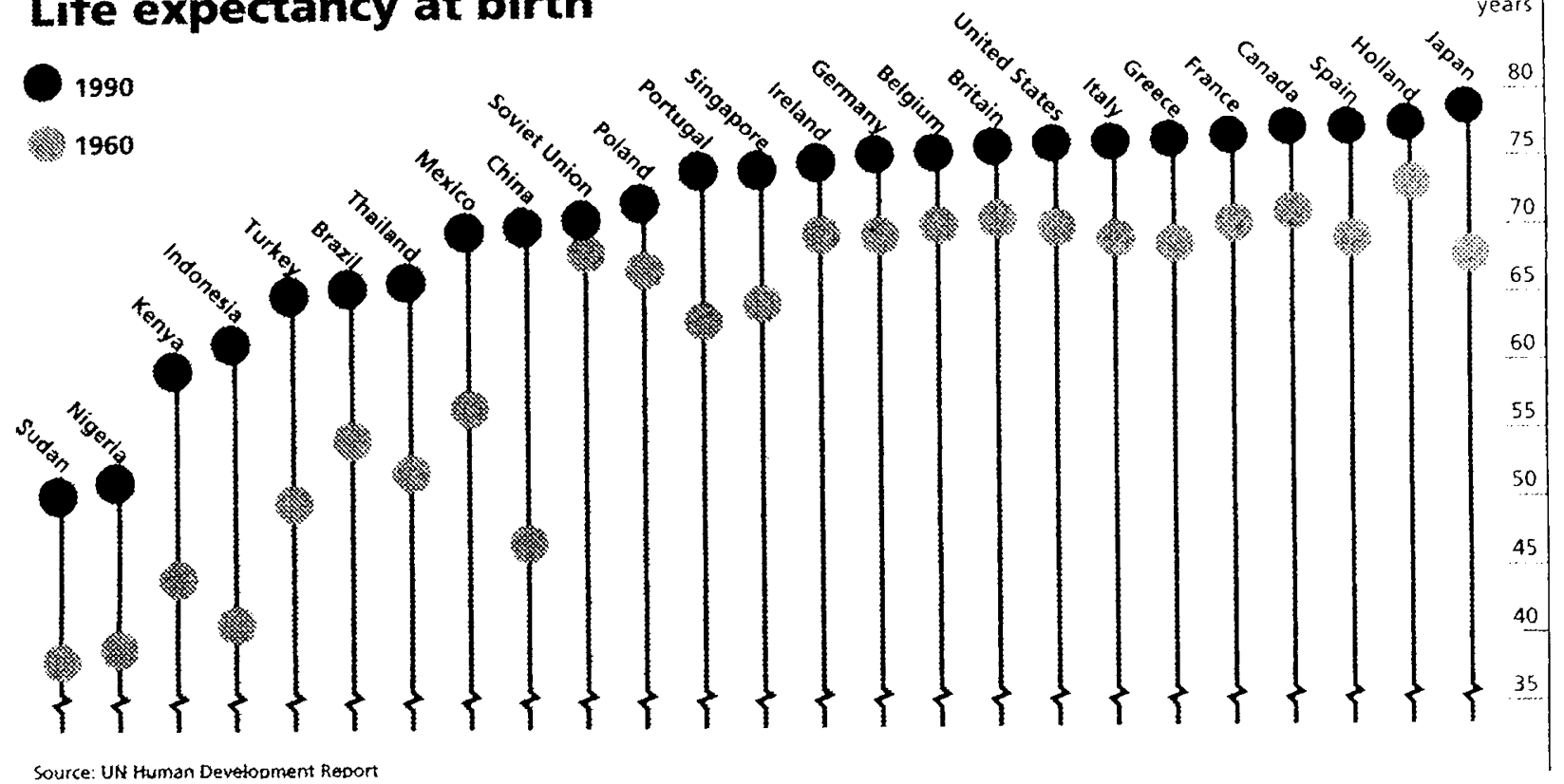

Figure 7. Improved life expectancy by country between 1960 and 1990. (Reproduced with permission from UN Human Development Report, The Economist Newspaper Group, Inc., 1991.)

we do not want. One benign way to stem population expansion and avoid its Malthusian consequences is to increase the interval between births, by voluntary contraceptive practices (Fig. 8). This has been called "the fifth freedom" for humankind. Unfortunately, it is widely opposed by strong forces.

Meanwhile, one might say that child care, through their effective wars and campaigns on pediatric disease, has been responsible for two major problems in human biology at the end of this century: too many people; and an increase in the relative importance of the diseases of aging (13).

The war against disease was assisted by revolutions that improved its armaments. The pharmacologic revolution, in addition to chemical contraceptives, introduced Ehrlich's "magic bullets," vitamins, antibiotics, vaccines, hormones, psychotropic drugs, and immunosuppressants. We have no magic bullets yet for cancers and germline genetic diseases, but "smart drugs," antisense RNA kits, and the like are apparently coming. A revolution in imaging methods improved diagnosis with x-rays, refinements in microscopy, endoscopy with fiber-

Medicel Progress: $20 t h \mathrm{C}$

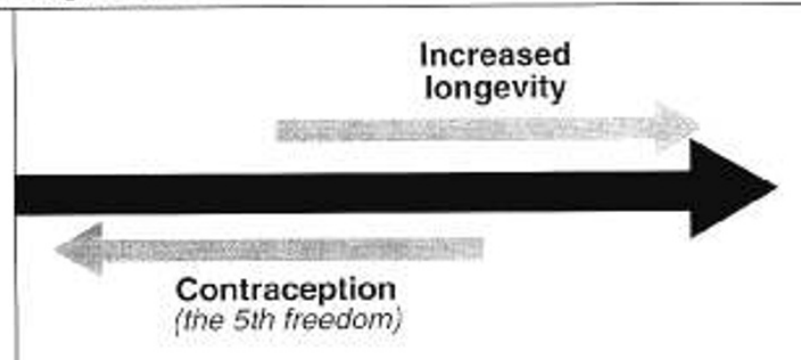

Small

Population Growth

Big

Figure 8. Relation between increased longevity, contraception ("the fifth freedom") and population growth. optics, ultrasound, and several approaches using noninvasive computerized scanning and magnetic resonance imaging methods. Yet another revolution, this one in surgery, introduced ways to extirpate, repair, and replace tissue. A totally different type of "surgery" involving genes is on the horizon.

All of this should be cause for joy. Instead, patients are increasingly unhappy because performance does not match expectation in the late 20th century. The doctor in Sir Luke Fildes' famous 19th century genre painting (Fig. 9) could do little for the sick child yet the picture implies he was respected. Today, good advice and treatment are likely to make a difference for that sick child, yet the physician is not correspondingly admired - and indeed is fair game for a lawsuit if there is the least disappointment in fulfillment of parental expectations. This ironic situation calls for both a response and an explanation.

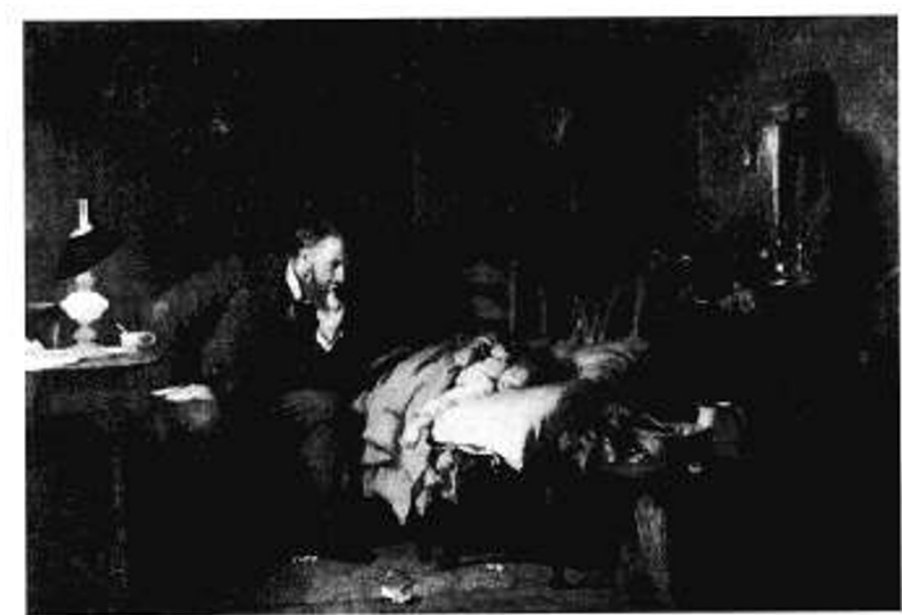

Figure 9. A famous 19th c. genre painting depicting a sick child, a parent, and the doctor. The relative importance of the personages in the drama seems indicated by the highlights in the picture. 
The Burden of Disease on Human Productivity

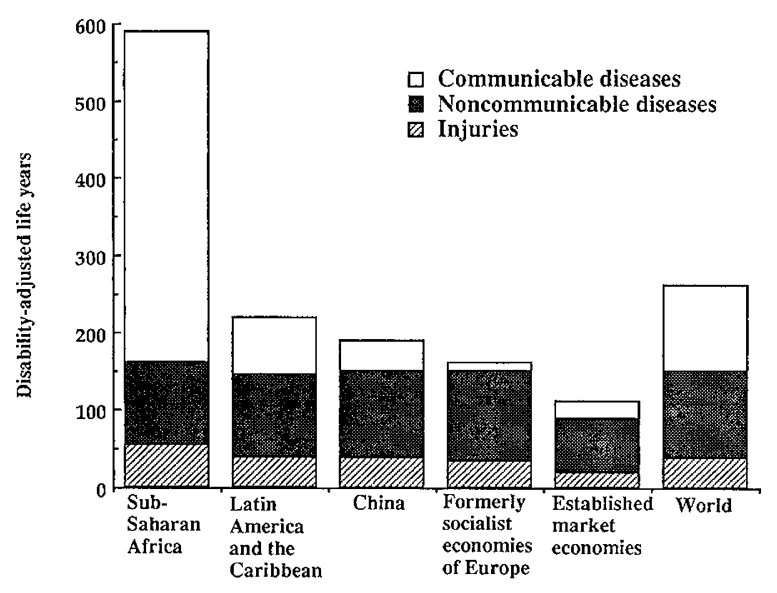

Figure 10. Heritability of diseases in regions and populations of the world (as reflected in relative prevalence of "noncommunicable diseases"). The $y$ axis is "disability adjusted life years," a parameter of productive person years lost by early death. (Adapted from various sources, including Science.)

A response is being initiated by those who are turning away from medicine's increasingly mechanistic approach to disease; they want a more holistic view taken of themselves. Accordingly, they seek solace in styles of medicine that are "alternative," "complementary," and "unorthodox"; a third of American adults are said to seek these alternatives (14). In recognition of this fact, the National Institutes of Health has established an Office of Alternative Medicine; and in the
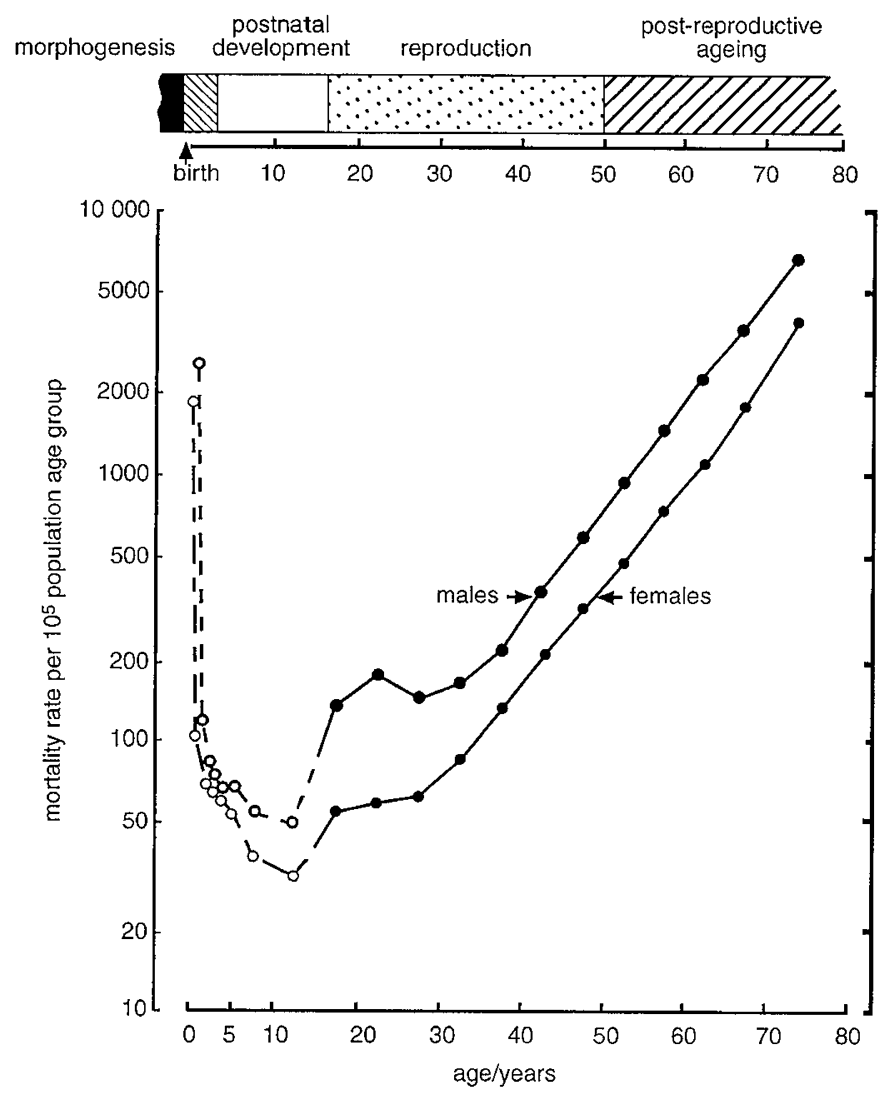

Figure 11. Age-specific mortality rates related to major human life intervals. (From Canadian Statistics in the 1980s.)

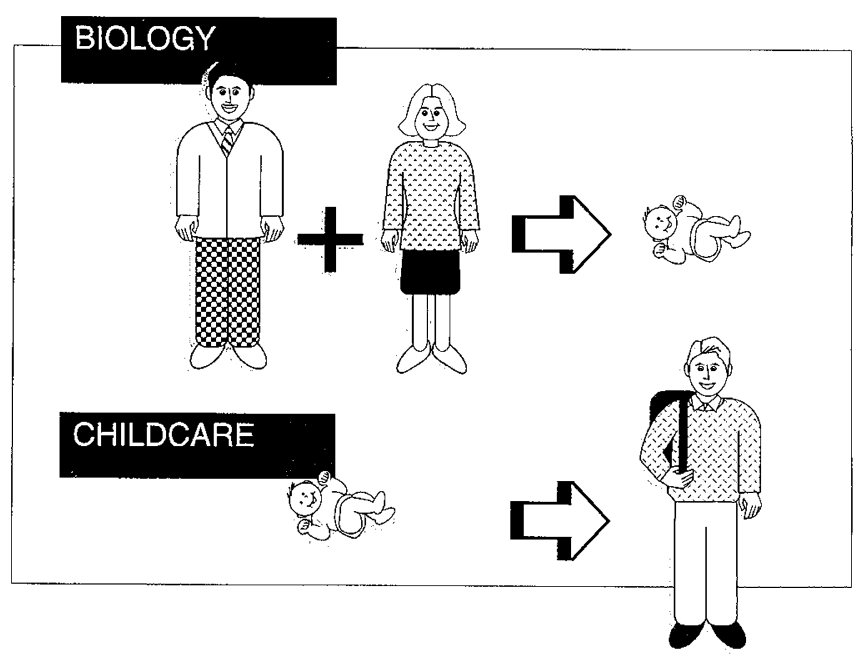

Figure 12. Biology is about the next generation and the perpetuation of (any) species; pediatrics (child care) is about this generation and protecting the prereproductive interval of life.

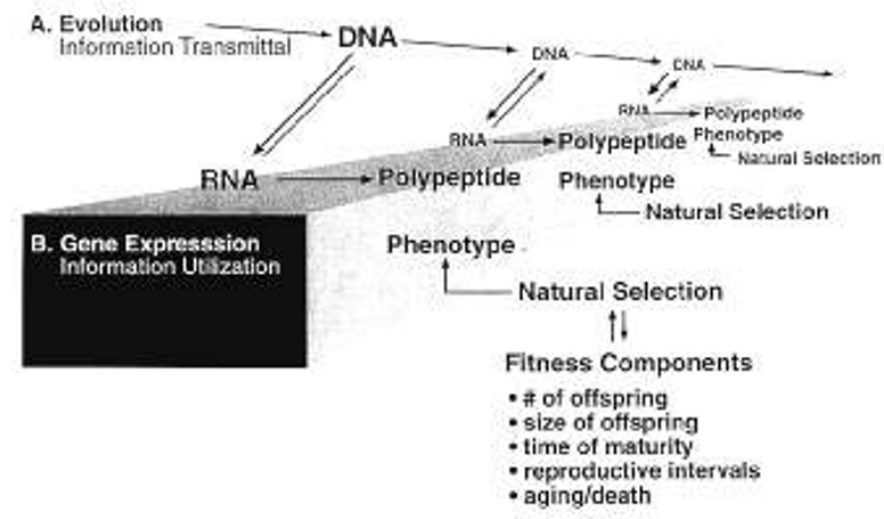

Figure 13. The major paradigms in biology are information transmittal (top) and information utilization (bottom).

United Kingdom, the Medical Research Council has a team analyzing back pain, chiropractic, and meditation. The explanation for public disaffection with conventional medicine (pediatrics included), is harder to find. I offer a hypothesis. The language of Osler improved the practice of medicine; the language of war changed its content. As the extrinsic causes of disease that overwhelm homeostasis are being brought under control, the biologic causes that "undermine" it (there's a word from The Great War), remained untouched and became relatively more important (Fig. 10). Geneticists say the heritability of disease has risen. This is not to say that new campaigns to control communicable disease such as AIDS and tuberculosis are not needed; or that strategies and policies to reduce the toll from injuries are irrelevant. Of course not. It only means that the intrinsic biologic causes of disease deserve equal recognition.

Sir Archibald Garrod, successor to Sir William Osler at Oxford, anticipated the relative importance of biologic causes of disease in his extraordinary book The Inborn Factors in Disease (15) and proposed that medicine should take the fact into account. Whereas the medical community took Osler to its bosom, it largely ignored Garrod because his proposal was 


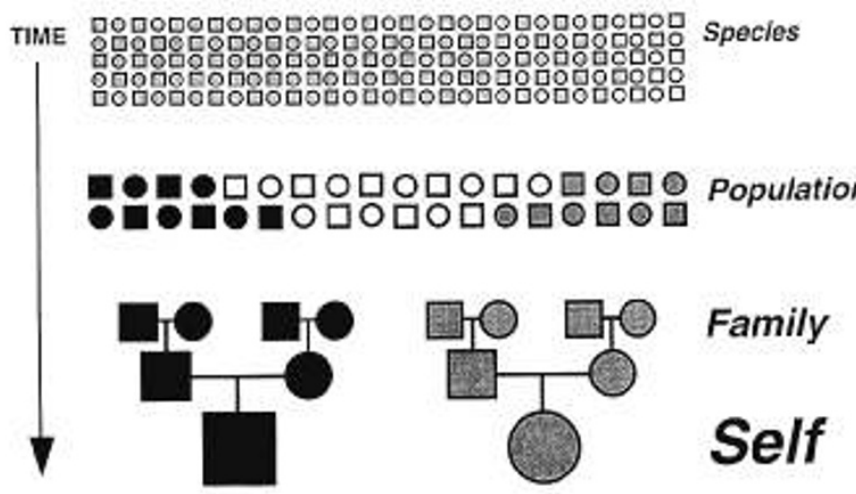

Figure 14. Self as a product of heredity and experience. The history of populations and the history of genes are contingent. History is an explanation for the nonrandom distribution of diseases.

premature. Garrod was suggesting that much human disease, even tuberculosis for example, reflected inherited susceptibility. In the course of time, he has been proven right about tuberculosis. Mutation in the Nramp gene in the mouse (natural resistance-associated macrophage protein) impairs the macrophage response to mycobacterial infection and confers susceptibility to tuberculosis disease (16); the homolog of Nramp is on chromosome $2 \mathrm{q}$ in the human genome. Age-specific mortality rates for the 1980s in Canada also confirm Garrod's view (Fig. 11). The rate is high in early life; it then falls as the reproductive years are approached, to rise again beginning in the 4th decade of life. Morbidity follows mortality. Disease in children now has a high genetic content $(17,18)$ as does early-onset disease of adults (19). If there is a logic of disease-and there most certainly is $(20,21)$-it follows that it will have a language. A language of war is illogical if the "enemy" is our own inherited susceptibility. The language of biology is called for.

\section{III}

\section{The Language of Biology for Medicine}

There is but one objective in all biologic programs; organisms must pass on their genes to save the species (Fig. 12). And there is but one objective of child care in all its forms; it is to help parents and society to raise children in health to maturity, ready to pass on their genes if they can and choose to do so.

Biology operates under only two paradigms (22). In one (Fig. 13), genetic information is replicated and transmitted to the next generation; the balance between fidelity and error in the transmission is the substrate of evolution. In the other paradigm, genetic information is used and translated into phenotypes. The link between one paradigm and the other is a central dogma of biology: DNA makes RNA makes protein. Since information cannot flow directly from protein to DNA, evolution occurs by the algorithm of natural selection; selection can act only on phenotype but the object selected is the gene for the phenotype. Fitness components are the quantitative measures of performance in the great game of chance. Human beings are special creatures in the evolution of organisms: they consciously modify the effects of selection. Homological evolution is a new venture in biology.

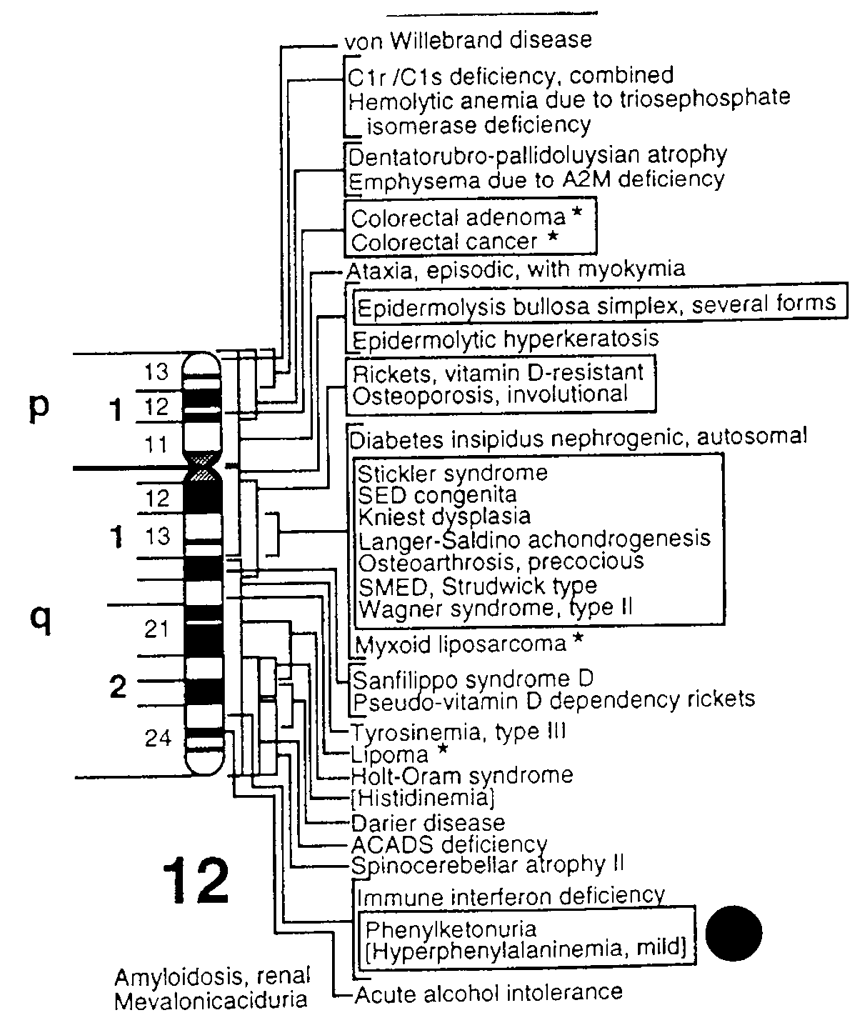

Figure 15. A genetic map of loci on chromosome 12 showing the $P A H$ gene in region 12q.24.1 (Reproduced with permission from McKusick VA, Amberger JS: Appendix 1-1. In: Scriver CR, Beaudet AL, Sly WS, Valle D (eds) The Metabolic and Molecular Bases of Inherited Disease, 7th Ed. McGrawHill, New York, 1995, p. 121.)

The neutral algorithm of natural selection, with no Divine Planner anywhere in sight, has been one of the most unsettling ideas ever produced by humankind (23). The possibility that you and I can bypass chance and control selection is, for many, an even more unsettling thought. In the midst of our discomfort, perhaps there is solace in George Santayana's advice: "There is no cure for birth or death save to enjoy the interval."

The algorithm and the paradigms of biology tell us that every phenotype has two histories (24): one rooted in the ultimate biologic memory of our genes, the other arising in proximate experience. Accordingly, Self-the person-is linked biologically to parents who, in turn, are linked to a community and eventually to the species Homo sapiens (Fig. 14). In our species, the history of populations is very often the history of genes. At the same time, the experiences encountered in families, among peers, and society and in the physical environment also shape us. The public version of our species comprises all the private versions of a human life. In pediatrics, the public version viewed from a biologic perspective includes all the private versions. It is a perspective different from and far better than a mere description of the diseases our patients have; we are invited to consider the person with the disease and to ask- "why does this particular member of the species have this specific disease at this moment?"

Ultimate causes of disease are transmitted according to Mendel's rules (modified occasionally by non-Mendelian events such as imprinting, mosaicism, uniparental disomy, 

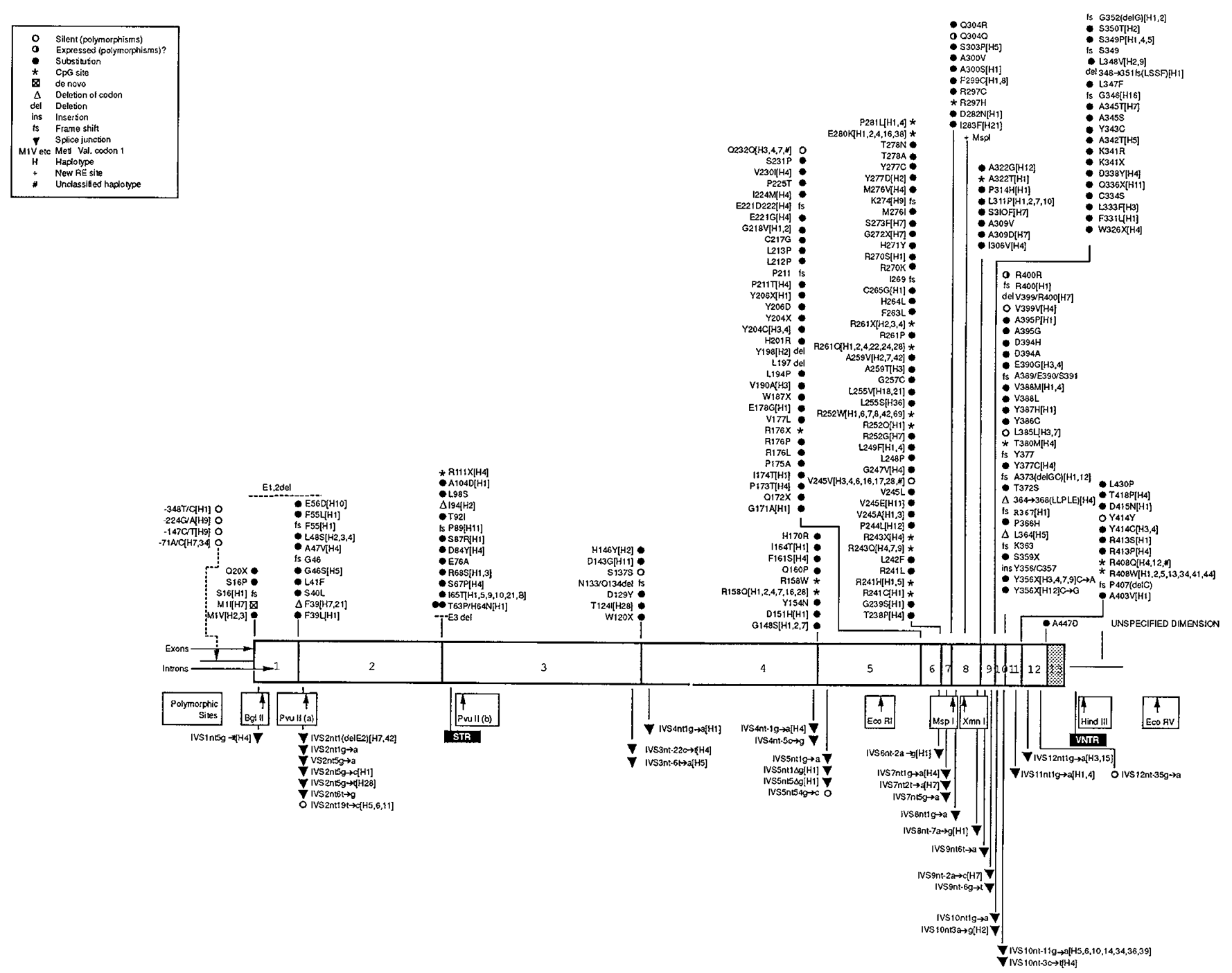

Figure 16. The human PAH gene, its major architecture over $90 \mathrm{~kb}$ of genomic DNA, the suite of polymorphic markers, and the mutations. (From PAH Mutation Analysis Consortium Database on June 26, 1995: Curators: C. R. Scriver, L. Hoang, S. Byck, and L. Prevost. Internet web address: http://www.mcgill.ca/pahdb.)

dynamic trinucleotide-repeat expansions, and mitochondrial inheritance) (25). The rate of change in genetic information by

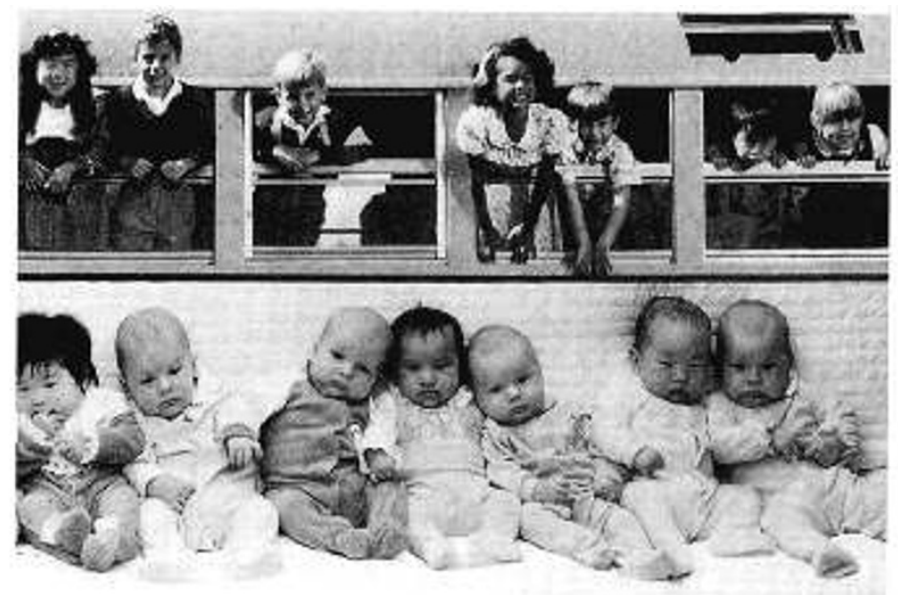

Figure 17. A visual metaphor for human developments. The infants (bottom half of the picture) were rephotographed when they had reached school age (top half). (Reprinted courtesy $\odot$ Eastman Kodak Company.) modification of DNA sequence, organization, or structure tends to occur at a glacial pace whereas proximate causes of disease can change overnight. In this century, the major efforts in health care have been to change experience and reduce proximate causes of disease. The inevitable result, as stated above, has been to increase the heritability of human disease. Whereas one cannot predict proximate experience, it is increasingly possible to identify biological risk residing in genetic variation; accordingly, hazard of disease can be anticipated in ways unknown to Osler or Garrod. [The terms "risk" and "hazard" are used as described by Hohenemser et al. (39).] Three examples illustrate these precepts:

Phenylketonuria. One of the most widely used genetic tests in the world is designed to detect newborn infants with hyperphenylalaninemia, a metrical trait associated with impaired cognitive development (26). The test allows early diagnosis and treatment to neutralize the major effects of the mutant gene. Ninety-nine percent of the allelic variation associated with hyperphenylalaninemia maps to a $90-\mathrm{kb}$ sequence of DNA on chromosome 12q; the gene encodes phenylalanine 


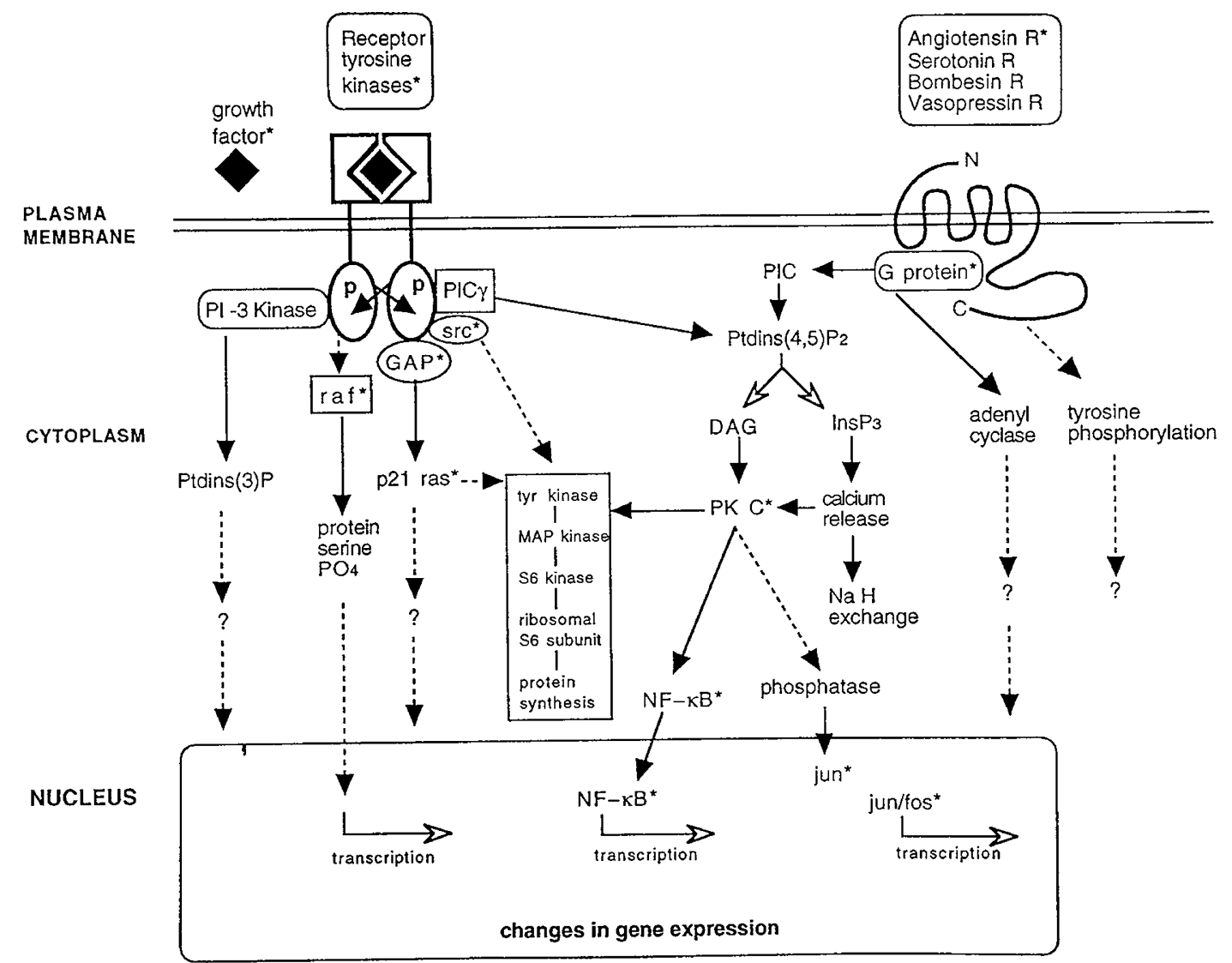

Figure 18. Pathways link growth factors, membrane receptors, cytoplasmic response mechanisms and the genome. (Reprinted with permission from Park M: Oncogenes: genetic abnormalities of cell growth. In: Scriver CR, Beaudet AL, Sly WS, Valle D (eds) The Metabolic and Molecular Bases of Inherited Disease, 7th Ed. McGraw-Hill, New York, 1995, p. 599.)

hydroxylase (Fig. 15). Over 230 different proven or putative disease-producing alleles at this locus (Fig. 16) have been reported by a Consortium of 81 investigators in 26 countries. Findings are recorded in a database maintained by myself and colleagues (27), and "in silico research" is now complementing research done in vivo, in vitro on this disease over the past 60 years. PAH mutations are a form of molecular prosopography, they stratify by geographic region and population history, and are proving to be tracers of migration, genetic drift, recurrent mutation, and perhaps selection; and of demic expansion and radiation. The PAH gene is both an example of biologic memory and an explanation for cases of mental retardation. It is a "hopeful" gene, and how to deal with its disease-producing alleles is an outstanding example of homologic evolution.

Congenital malformations. Parents hope their offspring will be born whole and well; most offspring match expectations and develop into healthy adults (Fig. 17). However, $5 \%$ of persons have a genetic disability by age 25 (28). Hereditary factors play a role in many congenital malformations (29), and the affected

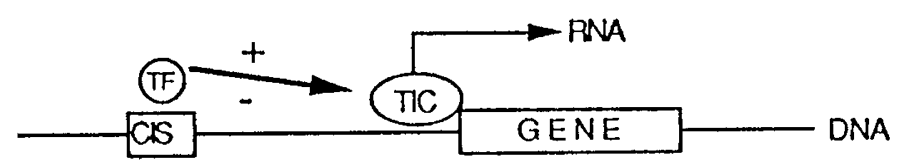

Figure 19. Transcription regulation by trans-acting factors $(T F)$ binding to cis elements $(C S)$ to control the transcription initiation complex $(T I C)$. [Reprinted with permission of John Wiley \& Sons, Inc., from Semenza (31).] patients pose important questions: Can the programs for development and differentiation be understood? Can the factors that cause them to deviate be anticipated and offset? The answers will come from many quarters, for example, through knowledge of: 1) metabolic traffic (30) mediated by protooncogene and other gene products, by cellular growth factors and their interactions with receptors generating a flow of secondmessenger information to the nucleus (Fig. 18). 2) Transcrip-
I
II
III
IV
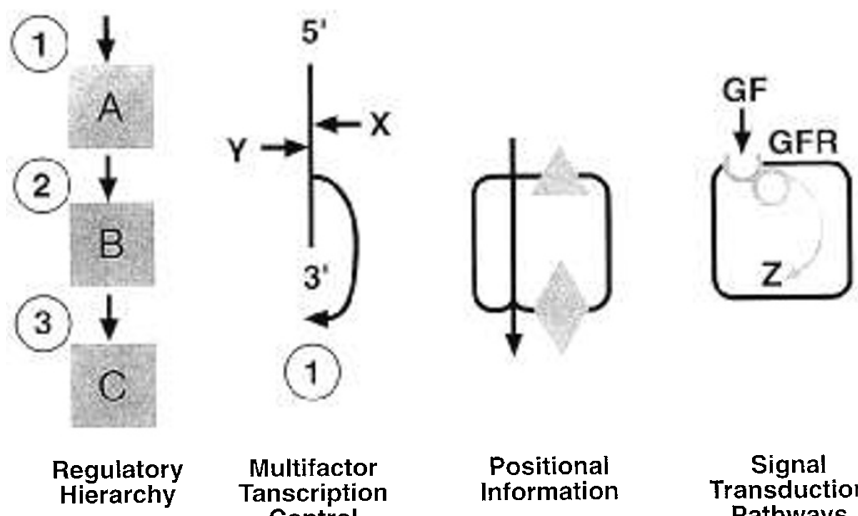

Figure 20. Four models of cellular programs for differentiation and development. 
'Normal' Metrical Phenotype

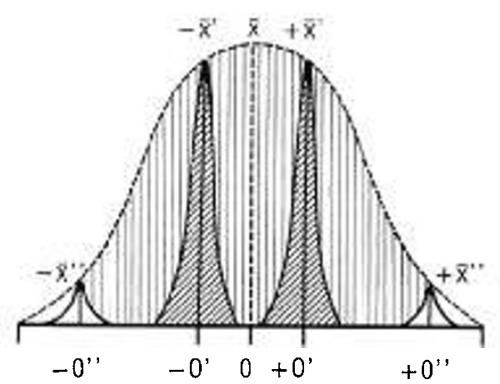

Figure 21. Idealized frequency distribution of a metrical trait. Within the larger population there will be subsets of distributions representing, for example, intraindividual variation, or clusters of individuals whose identity-by-state (the trait) reflects identity-by-descent (genetic). Major effects $\left(-\mathrm{x}^{\prime}, \mathrm{x}^{\prime},+\mathrm{x}^{\prime}\right)$ reflect common alleles and experiences $\left(0,0^{\prime}\right)$; marginal (outlier) effects $\left(-x^{\prime \prime}\right.$, $\left.+x^{\prime \prime}\right)$ usually reflect rare alleles or exceptional experiences $\left(0^{\prime \prime}\right)$.

tion-regulation of gene expression (31), by arrays of cis elements and the way they interact with arrays of trans-acting factors (Fig. 19). 3) Trajectories of development dependent on hierarchical interactions, multifactor transcription control, positional information at the cellular level and signal transduction pathways (Fig. 20). Congenital malformations will not be understood without the emerging language of biologic development.

The central tendency and birth weight. The principal product of natural selection is homeostasis (Fig. 21). Homeostatic systems are metrical traits and they have central tendencies representing optimal values for adaptation; outlier values (marginal traits) are at increased risk under selection and selection acts in the transition regions between order (homeostasis) and chaos (experience) (32). "Mediocrity" is the hard currency of adaptation; yet only human beings, in their strange ways, give prizes to the outliers of their species. There are few Mozarts; most of us are Salieris.

The frequency distribution of weight at birth is a classical illustration of central tendency in a human metrical trait (Fig. 22) and the relationship between birth weight and mortality rate is a classic example of homeostasis and stabilizing selection (33-35). Pediatricians are now required to make enormous

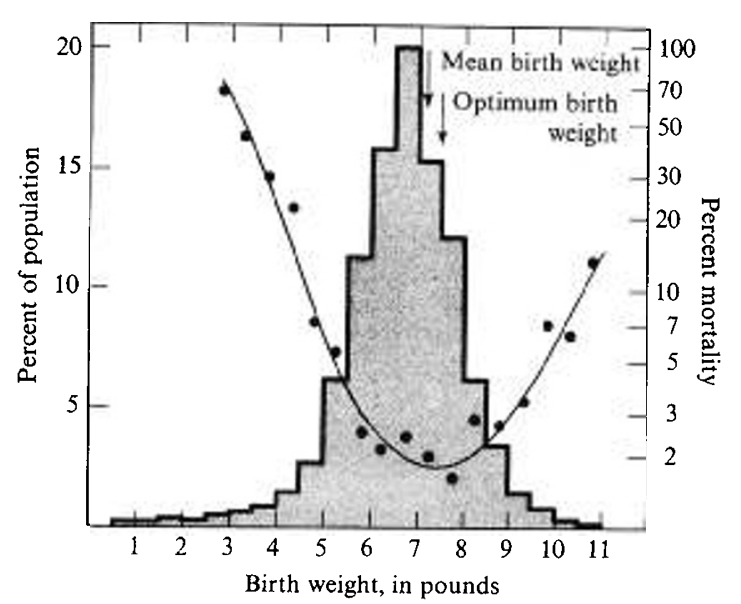

Figure 22. Birth weight and mortality rates of human infants at birth illustrate stabilizing selection. (Reprinted with permission from Ref. 35, p. 613.)

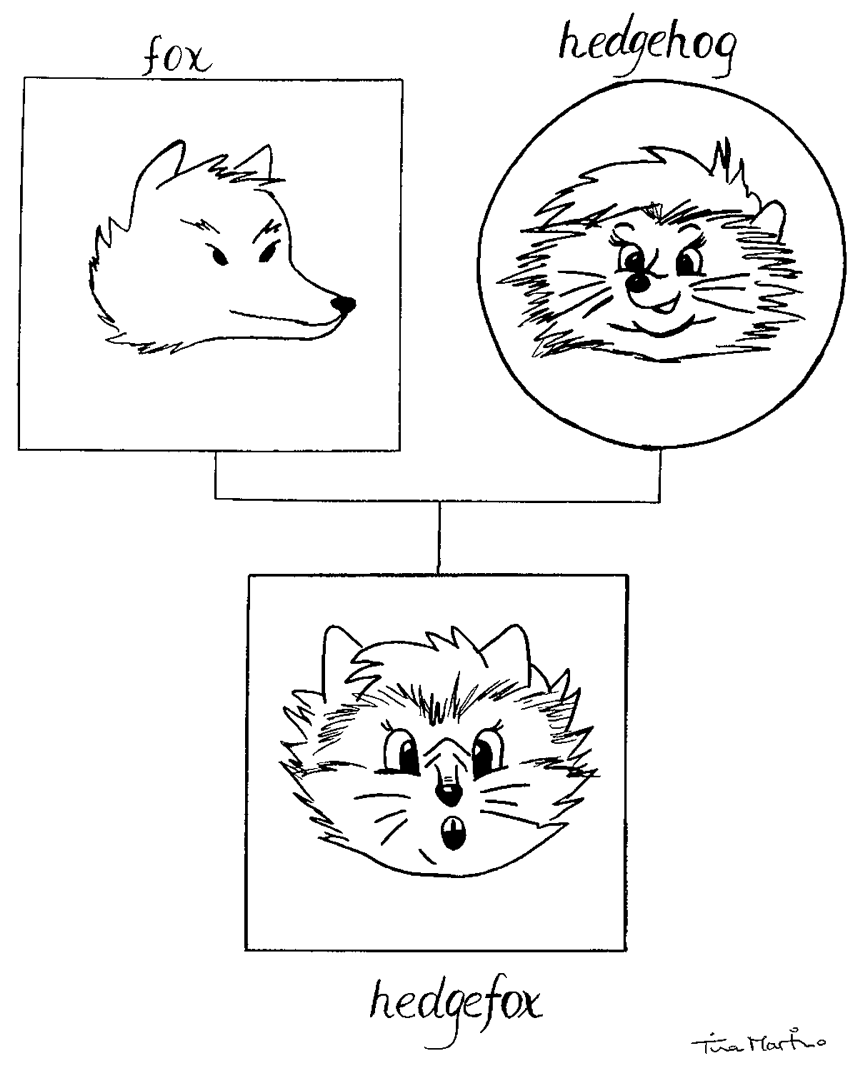

Figure 23. The hedgefox: a very special hybrid species. Whether the species thrives will depend on the reader. (Drawing by my colleague Tina Martino.)

efforts both to sustain the infant born too early and too small, and to record the high associated risk for neurobehavioral dysfunction and poor cognitive performance in later life (36). Meanwhile the fertility doctors make heroic efforts to ensure a supply of tiny infants, and few predictive factors responsible for untimely births have been identified. It is an area with an oversupply of questions and problems yet potentially rich in answers and solutions. The former presently reside under the taxonomy of pediatrics; the latter lie somewhere in biology, which means in the interactions between nature and nurture $(20,21,37)$.

\section{IV}

\section{A Fox or a Hedgehog}

There is a Greek saying: "The fox knows many things but the hedgehog knows one big thing" $(9,38)$. Osler's worry, expressed on May 2, 1892, could be restated this way: Pediatricians are in danger of becoming foxes.

If the hedgehog in this analogy knows one big thing, I suggest it is BIOLOGY. Biology is not categorical; it has the blurred edges of homeostastic systems, and it is exactly what we need. Wittgenstein knew something like this long ago [see Philosophical Investigations, para 71; cited in Stern (10)]. For those who want preordained answers and need to make dazzling clinical diagnoses, the language of biology in medicine may prove to be too inconclusive. But if the language of biology becomes the language for pediatrics, our discipline will survive the strong selection now acting on it. Moreover, its 
programs for education and training will change to produce, not more and better foxes along with the occasional hedgehog, but a hybrid natural for a recombinant era in medicine-the "hedgefox" (Fig. 23). [See proposals by Goldstein (6) and Foster (7) for a successful and adaptive career in the academic medical sciences.]

To close this Address, I offer two quotations:

- "All happy families are alike, but an unhappy family is unhappy after its own fashion" (Leo Tolstoy: Anna Karenina, line 1) [Tolstoy was a "hedgefox" (9).]

- "We shall not cease from exploration

And the end of all our exploring

Will be to arrive where we started

And know the place for the first time."

(T. S. Eliot: Little Gidding, lines 239-242).

Abraham Jacobi, in his Presidential Address to the APS in 1889 , offered ideas (5) that should be familiar if we care about our history; my own ideas are simply a persistent echo. If we know the past, and every good biologist does know it, we can celebrate every day as the last of it; at the same time, we can welcome fellow explorers to the first day of the future-which is every day. The voyage continues.

Acknowledgments. Lynne Prevost once again converted illegible manuscript into pristine diskette. I am grateful for support from the Medical Research Council of Canada, the Quebec Network of Genetic Medicine, and Les Fonds de la Recherche en Santé du Québec. The themes of this Address reflect the influences of Barton Childs, friend and mentor; dialogue with Dan Foster, Joseph Goldstein, and Lloyd Smith on education and training in medicine, work with colleagues of many years, conversations with my Dean and friend, Richard L. Cruess, and the support of McGill University and Montreal Children's Hospital, my academic homes.

\section{REFERENCES}

1. Scriver CR 1975 Genetics: voyage of discovery for everyman. Presidential Address to the Society for Pediatric Research, April 29, 1976, St. Louis, Missouri. Pediatr Res 10:865-872

2. Faber HK, McIntosh R 1966 History of the American Pediatric Society, 1887-1965. McGraw-Hill, New York

3. Scriver CR 1990 Questions to the past that resonate in the present. Pediatr Res 27:S17-S19

4. Hobsbawm E 1994 The Age of Extremes: A History of the World, 1914-1991. Michael Joseph and Pelham Books, London

5. Pearson HA 1995 Pediatric history. The American Pediatric Society. Pediatrics 95:147-151

6. Goldstein JL 1986 On the origin and prevention of PAIDS (paralyzed academic investigator's disease syndrome). J Clin Invest 78:848-854

7. Foster DW. What constitutes an optimal education for the future academic subspecialist: integration of science and medicine? In: Blank LL (ed) Report of the 1994
Summer Conference: The Role and Education of the Medical Specialist in the 21st Century. American Board of Internal Medicine, Philadelphia, 1994, pp 59-61

8. Cushing H 1925 The Life of William Osler. Oxford University Press, New York

9. Smith LHJ. An historical overview of the development of medical subspecialities. In: Blank LL (ed) Report of the 1994 Summer Conference: The Role and Education of the Medical Specialist in the 21st Century. American Board of Internal Medicine, Philadelphia, 1994, pp 21-26

10. Stern JP 1992 The Heart of Europe. Essays on Literature and Ideology. Wittgenstein in Context. Blackwell Pub., Cambridge, MA, pp 367-389

11. Forfar JO 1991 J.H. Hutchison Memorial Lecture. Paediatrics in a changing world. International Child Health: A Digest of Current Information 2(3):1-12

12. Lakoff G, Johnson M 1980 Metaphors We Live By. University of Chicago Press, Chicago

13. Campion EW 1994 The oldest old. N Engl J Med 330:1819-1820

14. Trachtman P 1994 NIH looks at the implausible and the inexplicable. Smithsonian $25: 110-123$

15. Scriver CR, Childs B 1989 Garrod's Inborn Factors in Disease (Oxford Monographs in Medical Genetics: 16). Oxford University Press, New York

16. Vidal SM, Malo D, Vogan K, Skamene E, Gros P 1993 Natural resistance to infection with intracellular parasites: isolation of a candidate for $B c$. Cell 73:469-485

17. Roberts DF, Chavez J, Court SDM 1970 The genetic component in child mortality. Arch Dis Child 45:33-38

18. Hall JG, Powers EK, McIlvaine R, Ean VH 1978 The frequency and financial burden of genetic disease in a pediatric hospital. Am J Med Genet 1:417-436

19. Childs B, Scriver CR 1986 Age at onset and causes of disease. Perspect Biol Med 29:437-460

20. Childs B 1995 A logic of disease. In: Scriver CR, Beaudet AL, Sly WS, Valle D (eds) The Metabolic and Molecular Bases of Inherited Disease, 7th Ed. McGraw-Hill, New York, pp 229-257

21. Childs B 1989 Book Review: Human Biology: An Introduction to Human Evolution, Variation, Growth and Adaptability, 3rd Ed., by G. A. Harrison, J. M. Tanner, D. R. Pilbeam, and P. T. Baker, Oxford Universtiy Press, New York, 1988. Am J Hum Genet 44:593-595

22. Stearns SC 1992 The Evolution of Life Histories. Oxford University Press, New York 23. Dennet DC 1995 Darwin's Dangerous Idea. Simon \& Schuster, New York

24. Scriver CR 1993 Every disease has two histories. Trans R Soc Can Ser VI 4:24-38

25. Hall JG 1990 Non-traditional inheritance. Growth Genet Horm 6:1-4

26. Scriver CR, Kaufman S, Eisensmith RC, Woo SLC 1995 The hyperphenylalaninemias. In: Scriver CR, Beaudet AL, Sly WS, Valle D (eds) The Metabolic and Molecular Bases of Inherited Disease, 7th Ed. McGraw-Hill, New York, pp 1015 1075

27. Scriver CR, Hoang L, Byck S, Prevost L 1995 Database of Allelic Variation for the PAH Mutation Analysis Consortium at http://www.mcgill.ca/pahdb.

28. Baird PA, Anderson TE, Newcombe HB, Lowry RB 1988 Genetic disorders in children and young adults: a population study. Am J Hum Genet 42:677-693

29. Lie RT, Wilcox AJ, Skjerven R 1994 A population-based study of the risk of recurrence of birth defects. N Engl J Med 331:1-4

30. Park M 1995 Oncogenes: genetic abnormalities of cell growth. In: Scriver CR, Beaudet AL, Sly SW, Valle D (eds) The Metabolic and Molecular Bases of Inherited Disease, 7th ed. McGraw-Hill, New York, pp 589-611

31. Semenza GL 1994 Transcriptional regulation of gene expression: mechanisms and pathophysiology. Hum Mutat 3:180-199

32. Kauffman SA 1994 The Origins of Order. Self-organization and Selection in Evolution. Oxford University Press, New York

33. Karn MN, Penrose LS 1951 Birthweight and gestation time in relation to maternal age, parity and infant survival. Ann Eugenics 15:206-233

34. Terrenato L, Gravina MF, San Martini A, Ulizzi L 1981 Natural selection associated with birthweight. III. Changes over the last twenty years. Ann Hum Genet 45:267278

35. Cavalli-Sforza LL, Bodmer WF 1971 The Genetics of Human Populations. W. H. Freeman, San Francisco

36. Hack M, Taylor HG, Klein N, Eiben R, Schatschneider C, Mercuri-Minich N 1994 School-age outcomes in children with birthweights under $750 \mathrm{~g}$. N Engl J Med 331:753-759

37. McCormick MC 1994 Survival of very tiny babies-good news and bad news. N Engl J Med 331:802-803

38. Berlin I 1953 The Hedgehog and the Fox. An Essay on Tolstoy's View of History. Simon \& Shuster, New York

39. Hohenemser C, Kates RW, Slovic P 1983 The nature of technological hazard. Science $220: 376-384$ 